\author{
MICHAt LUBINA \\ Uniwersytet Jagielloński \\ ORCID ID: https://orcid.org/0000-0002-3342-1763
}

\title{
Rosja Władimira Putina a Chiny Xi Jinpinga \\ O wpływie przywódców politycznych na politykę w państwach autorytarnych: przypadki rosyjski i chiński
}

\section{Putin's Russia and Xi's China. The Influence of Political Leaders on Politics in Authoritarian Countries: Case Studies of Russia and China}

\section{Abstract}

In political science an accent on individuals (political leaders) in researching politics is neither popular nor advocated one. In authoritarian countries like Russia or China, however, political leaders and their personalities are a crucial factor in trying to understand the political processes there. Both Vladimir Putin in Russia and Xi Jinping in China have dominated their respective political systems. This, combined with good state of Russia-China relations makes it an interesting case study of the influence of political leaders on authoritarian countries. Both Putin and $\mathrm{Xi}$ are new type of leaders: they both follow the main ideas of political realism (though with "national differences") and they share a $19^{\text {th }}$ century outlook on the global affairs ("concert of powers") yet they use contemporary means to fulfil these interests. Their personal understanding provides a predictability and stability: both Putin and Xi function in accordance with balance of power and respect for zones of influence concepts. That is why differences in other spheres, like Russia's and China's approaches to the USA do not influence the general good mood of Sino-Russian relationship.

Keywords: Vladimir Putin, Xi Jinping, Russia-China, Sino-Russian relations 


\section{Россия Путина и Китай Си Цзиньпина. Влияние политических лидеров на политику в авторитарных странах. Примеры российский и китайский}

\section{Аннотация}

В политических науках фокус на политических лидеров не является популярным. Однако, в авторитарных странах, таких как Россия и Китай, это лидеры имеют ключевое значение для понимания политических процессов. Владимир Путин и Си Цзиньпин доминировали российский и китайский политические системы, что, в связи с хорошими российско-китайскими отношениями, является интересным примером в исследовании влияния политических лидеров на политику. Путин и Си Цзиньпин - это лидеры нового типа. Они оба - политические реалисты, хотя с «национальными» отличиями, у них похожее видение мира с перспективы концепции системы концерта держав и одновременно современные средства осуществления государственных интересов. Взаимопонимание между Путиным и Си Цзиньпином, схожая политическая философия, диктовавшая уважение собственных зон интересов и сохранение баланса сил, положительно влияют на российско-китайские отношения. Хотя и существуют отличия между Россией и Китаем (например, в вопросе политики в отношении США), они не влияют на хорошее состояние российско-китайских отношений".

Ключевые слова: Владимир Путин, Си Цзиньпин, Россия и Китай, российско-китайские отношения

\section{Wstęp. Jednostki w naukach o polityce}

W naukach politycznych badanie jednostek - polityków, działaczy, aktywistów - nie jest premiowane. W zachodniej tradycji uprawiania politologii zdecydowanie bardziej ceni się akcent na instytucje, normy, zasady itp. (Keohane, 1986, s. 198). Za tą postawą przemawia szereg argumentów, z których najważniejszym jest przekonanie, iż takie procesy jak globalizacja czy demokratyzacja zmniejszyły rolę jednostek na rzecz norm i zasad instytucjonalnych. Tak bez wątpienia jest $\mathrm{w}$ demokracjach $-\mathrm{z}$ istotnymi wyjątkami, takimi jak Donald Trump - gdzie system kontroli i równoważników został stworzony by uniemożliwić wykorzystywanie i nadużywanie władzy przez żądne władzy jednostki. To powoduje, że w demokracjach generalnie - rola jednostek zmniejsza się. 
Główną tezą badawczą tego artykułu jest założenie, że w państwach autorytarnych, takich jak Rosja i Chiny rola jednostek nie tylko nie zmniejsza się, ale pozostaje istotnym elementem kształtowania polityki tych państw. Teza ta zostanie przedstawiona na przypadkach rosyjskim i chińskim, co służyć będzie przedstawieniu dalszych tez, takich jak: dominacja rosyjskiego systemu politycznego przez Putina i chińskiego przez Xi Jinpinga; zbliżenie rosyjsko-chińskie na poziomie elit motywowane przez korporacyjne interesy reżimu rosyjskiego czy utrzymujący się dystans między społeczeństwami niewpływający jednak na politykę państw z powodu małego znaczenia społeczeństw w polityce państwa autorytarnych.

Mimo istniejących oczywistych i zasadniczych różnic kulturowych między warunkami rosyjskimi a chińskimi oba te przypadki są porównywalne. Kraje te łączy tradycja poufności władzy, do której dostęp jest utrudniony i ograniczony do wybranych szczęśliwców. Procesy decyzyjne są podejmowanie przez małe grupy decydentów z przywódcami na czele kosztem oficjalnych struktur państwowych i partyjnych, formalnie odpowiedzialnych za proces legislacyjnych, które tylko formalizują decyzje już podjęte (Lo, 2008, s. 17). W takich państwach ma miejsce prymat jednostek nad instytucjami: to jednostki - przywódcy polityczni - z ich siecią kontaktów osobistych mają znacznie większe znaczenie od instytucji formalnie powołanych do rządzenia; jednostki tworzą instytucje, a nie odwrotnie - wpływ instytucji może się zmniejszać lub zwiększać w zależności od pozycji reprezentujących je patronów; to jednostki, nie instytucje czy idee mają decydujące znaczenie w „dworskiej” polityce Moskwy czy Pekinu; ten personalistyczny model jest odwzorowany na niższych szczeblach władzy (Lo, 2015, ss. 10-19). Połączona z tym silna tradycja tajności i działań nieformalnych tworzy „dwa polityczne otoczenia: realne i wirtualne (te drugie jest dostępne dla opinii publicznej) - świat realny jest wyłączony i niewidzialny, ale to tam zapadają najważniejsze decyzje; w tym modelu większość klasy politycznej odgrywa niewielką rolę, opinia publiczna niemal żadną, zaś włodarze działają zgodnie z zasadą »im mniej (dostępu) tym lepiej «", gdyż tworzy to spójność, bezpieczeństwo i jest efektywne - bez dostępu do uprzywilejowanego świata władzy często niemożliwe jest ustalenie kto wpłynął na kogo i w jaki sposób; tworzy to środowisko, w którym »ci którzy wiedzą, nie mówią, zaś ci którzy mówią - nie wiedzą« (ibidem, s. 5). To powoduje, że rzadko kiedy można ustalić genezę 
danej decyzji: to wyjawia się dopiero po czasie (a i tak nie zawsze). W tej sytuacji czynnik ludzki - przywódca z jego osobowością - nadal w decydujący sposób wpływa na historię, zachowania i politykę państwa. Dzieje się tak, gdyż realna władza wciąż spoczywa w rękach jednostek lub grup jednostek, nie będąc kontrolowana i równoważona przez inne władze, tak jak to ma miejsce lub przynajmniej powinno mieć miejsce w demokracjach. W państwach autorytarnych struktury oficjalne tylko formalizują lub zatwierdzają decyzje już dawno podjęte. Dlatego właśnie znaczenie jednostek wzrasta w systemach autorytarnych. Tutaj role i możliwości jednostki zależą od zakresu władzy przez nią posiadanej lub w rękach wąskiej grupy ją otaczającej (Dmochowski, 2008, s. 62).

Tak jest właśnie zarówno w przypadku Rosji, jak i Chin, gdzie proces decyzyjny znajduje się w rękach małej grupy z przywódcą na czele, podejmującej kluczowe decyzje często podczas nieformalnych spotkań. Tak jest zarówno w Rosji, gdzie Władimir Putin zdołał stworzyć własny -izm, jak i w Chinach, gdzie Xi Jinping zakwestionował istniejący od trzydziestu lat konsensus.

\section{Rosja Putina}

Dojście do władzy Władimira Putina wzmocniło Rosję na świecie. Putin doszedł do wladzy z hasłami wzmocnienia, stabilizacji i przywrócenia dawnego znaczenia na arenie międzynarodowej i w dużej mierze uzyskał te cele. Od czasu objęcia władzy Putin modernizował Rosję przy pomocy tradycyjnego paradygmatu władzy w tym kraju: silnej i bezwzględnej władzy centralnej. Rosyjski przywódca jest klasycznym przedstawicielem szkoły „państwowców”; podstawowym założeniem tej szkoły jest przekonanie, iż bez silnego państwa Rosja się rozpadnie, zaś przy silnej władzy odbuduje potęgę. W tym podejściu to, co korzystne dla państwa rosyjskiego jest dobre dla Rosji. Putinowska odbudowa państwa w duchu „państwowców” stała się szczególnie atrakcyjna po jelcynowskim chaosie lat 90. (Лукин, 2013, s. 326). Może chociaż raz Władimir Putin personifikuje więc pogląd, że państwo ważniejsze jest od jednostek i uważa że podstawowym celem władzy jest wzmocnienie państwa (Rozman, 2014, s. 110-122). Postawa rosyjskiego prezydenta wynika z głębokiego zrozumienia rosyjskiej historii: 
państwo musi być silne by obronić się przed zarówno zewnętrznymi wrogami, jak i żądaniami własnych obywateli; ten paradygmat implikuje konieczność posiadania statusu mocarstwa (Pipes, 2004). Ponieważ postawa Putina była i jest zgodna $\mathrm{z}$ tradycyjnymi wzorami władzy, większość społeczeństwa rosyjskiego zaakceptowała jego rządy (lub była im obojętna), gdyż przywracały one dumę narodową i poczucie mocarstwowości. Ponadto, jeśli nie przede wszystkim, Putin przez długi czas gwarantował stabilność, spokój społeczny i relatywne prosperity (Malczyk, 2014) oraz przywrócił marzenia o potędze Rosji. Krótko mówiąc, Putin stworzył obraz Federacji Rosyjskiej zarządzanej przez niego, jako państwa paternalistycznego będącego w stanie zapewnić ludności podstawowe potrzeby, uzyskać rozwój i zamarzyć o ponownym staniu się mocarstwem (Lukin, 2009, ss. 56-92). Mając za patronów Piotra I i Piotra Stołypina Władimir Putin uwierzył ponoć, iż przeznaczenie Rosji jest w jego rękach (Rozman, 2014, s. 118).

Z punktu widzenia systemu politycznego rosyjski przywódca od momentu dojścia do władzy starał się ustanowić swoją władzę osobistą poprzez kontrolę władzy rozchodzącej się wertykalnie: w ten sposób, nawiązując do tradycyjnego wzorca. Chciał w ten sposób odbudować siłę państwa rosyjskiego poprzez koncentrację władzy w rękach Kremla (Kaczmarski, 2015, 37; Hill, Gaddy 2015, s. 219). Opowiadał się za hierarchicznym modelem państwa, konsolidacją władzy centralnej i ograniczeniem władzy regionalnych „książąt udzielnych”, zażegnał zagrożenie secesji rozpadu państwa, a przede wszystkim pożegnał skompromitowane idee demokracji i liberalizmu, opowiadając się za centralizacją władzy i stworzeniem systemu półautokratycznego. (Rumer, Wallander, 2003/2004, ss. 57-73). Szczególnie po 2003 r. i rozgrywce z Chodorkowskim i skutecznym ograniczeniu wpływu oligarchów, Putin zaczął tworzyć nową, hierarchiczną strukturę władzy na czele ze sobą i grupą swoich kolegów. Putin od tego momentu rządzi dzięki kontroli szeregu kluczowych instytucji politycznych, takich jak biurokracja państwowa, służby specjalne, agencje siłowe, armia (i kompleks wojskowo-przemysłowy) oraz Gazprom i Rosoboroneksport (państwowa agencja handlu bronią). Do jego grona najbliższych zauszników należą lub należeli: Igor Sieczin, Dmitrij Miedwiediew, Sergiej Iwanow (do sierpnia 2016), Władysław Surkow, Aleksiej Kudrin, Anatolij Sierdiukow, Nikolaj Patruszew i Sergiej Szojgu. Podczas pierwszych dwóch kadencji, 
podczas których rządził Rosją Władimir Putin, grupa ta rządziła za pomocą mechanizmu „pluralizmu potężnych”. Od 2012 r. i objęcia przez Putina trzeciej kadencji zdołał on poszerzyć swoją władzę osobistą i zmniejszyć znaczenie kręgu swoich najbliższych zauszników (Kaczmarski, 2015, s. 41). Zdołał on w ten sposób stworzyć model „Zwiększonego patrymonialnego aktywizmu” (Lo, 2015). Spowodowało to, że władza osobista Putina w 2018 r. jest znacznie większa i potężniejsza niż była w poprzedniej dekadzie, o początkach kariery prezydenckiej nie wspominając. To powoduje, że władza w Rosji coraz bardziej spoczywa na osobowości przywódcy niż na instytucjach, zaś rola Putina stała się kluczowa dla stabilności współczesnego systemu politycznego Rosji (Kaczmarski, 2015, s. 37). Putin stworzył system „patronackiego prezydencjonalizmu” w Rosji (Mommsen, 2012), w którym wszyscy muszą konsultować swoje decyzje z Putinem; również poprzez kontakty z nim, „dojście” do niego i bycie częścią dworu putinowscy urzędnicy legitymizują swoją pozycję i swoje pomysły (Hill, Gaddy, 2015, s. 219). Putin stał się nową polityczną ikoną Rosji, zaś jego publiczny wizerunek pewności siebie i bezkompromisowości stały się wyznacznikiem nowej Rosji, jakże odmiennej od słabej, upokorzonej Jelcynowej Rosji z lat 90. To spowodowało, że to do Putina należy ostatnie słowo w kluczowych decyzjach, on sam zaś stoi na czele spersonalizowanej piramidy władzy, czego nie udało się stworzyć żadnemu przywódcy rosyjskiemu od czasów Stalina. To właśnie dzięki temu Putin uzyskał swój -izm: „putinizm” to hybryda scentralizowanej władzy politycznej, ekonomicznego oparcia się na rencie surowcowej, materializmu społecznego, konserwatywnej moralności i asertywnej postawy międzynarodowej (Lo, 2015, s. 7). To właśnie Władmir Putin wpływa na rosyjską politykę zagraniczną, w tym na relacje z Chinami.

\section{Putin, elity kremlowskie i Chiny}

W przeciwieństwie do Borysa Jelcyna, Władimir Władimirowicz Putin przystępował do władzy lepiej znając świat i rozumiejąc implikacje wzrostu Chin. Zrozumiał, że partnerstwo z Chinami nie jest dla Rosji luksusem, ani nawet kwestią wyboru, lecz absolutną koniecznością (Bieleń, 2006, s. 328). Już w 2000 r. Putin w swoim artykule Rosja: nowe wschodnie 
perspektywy deklarował, iż Rosja nie zapomniała, że większość jej terytorium leży w Azji (Сmamıя..., 2000). Za czasów Putina polityka zagraniczna Rosji stała się bardziej zrównoważona wobec uprzednio prozachodniej orientacji Jelcyna i bardziej skoncentrowana na Azji, zaś relacje z Chinami przestały być tylko funkcją relacji Rosji z Zachodem. Podczas gdy w latach 90. poza geopolityką mało było konkretów w relacjach rosyjsko-chińskich, to za rządów Władimira Putina stosunki rosyjsko-chińskie napełniły się namacalną treścią: doszły nowe aspekty - gospodarka, rosnący handel, rozwijająca się współpraca w wielu obszarach. Poprawiły się relacje pomiędzy Rosją a Chinami, m.in. dzięki większej kompetencji strony rosyjskiej, znacznie lepiej rozumiejącej realia światowe od ekipy Jelcyna (Lo, 2008, s. 39).

To wszystko doprowadziło do rozwoju relacji rosyjsko-chińskich: pogłębiły się one i znormalizowały: udało się zakończyć demarkację granicy, wzrósł obrót handlowy, zintensyfikowała się współpraca w Azji Środkowej, uspokojone zostały antychińskie resentymenty na Rosyjskim Dalekim Wschodzie (Lubina 2014, s. 187-541). Stopniowo Chiny stawały się jednym z najważniejszych partnerów Rosji, będąc nie tylko, mniej lub bardziej konkretną, alternatywą wobec Zachodu, jak to miało miejsce w poprzedniej dekadzie. Z dzisiejszej perspektywy jedynie Stany Zjednoczone są dla Rosji ważniejsze niż Chiny.

Chiny stały się czynnikiem w rosyjskiej polityce wewnętrznej, co miało odzwierciedlenie instytucjonalne oraz osobowe (Lubina 2017, s. 53-61). Poprzednio kontakty z Chinami były po stronie rosyjskiej chaotyczne i nieskoordynowane, charakteryzujące się przygotowywaniem ad hoc agendy na kolejne szczyty na najwyższym szczeblu, niekończącymi się negocjacjami w kwestiach energetycznych. Od drugiej dekady XXI w. powołano nową komisję międzyrządową na czele $\mathrm{z}$ wicepremierem Igorem Szuwalowem, wpływową postacią w kremlowskich elitach władzy; to właśnie ta komisja była miejscem kluczowych negocjacji długofalowych kontraktów na energię. Ponadto zausznik Putina, Giennadij Timczenko jest współprzewodniczącym Rosyjsko-Chińskiej Rady Biznesowej (Gabuev, 2016). Do tego dochodzą międzyrządowe komisje ds. dialogu energetycznego oraz kultury. Ogółem za relacje rosyjsko-chińskie odpowiada wiele urzędów, powodując tradycyjne w rosyjskich warunkach opóźnienia i nakładanie się kompetencji (Китайцы понимают..., 2015). Rozrost biu- 
rokracji pokazuje znaczenie Chin dla państwa rosyjskiego. Na poziomie osobowym w ostatnich dwóch dekadach wielkim orędownikiem rozwoju relacji rosyjsko-chińskich był Igor Rodionow, były ambasador Rosji w Pekinie, który po ustąpieniu z funkcji w 2005 r. pozostał bardzo wpływową postacią, do swojej śmierci w 2012 r. (Лукин, 2015, s. 318; Lo, 2015, s. 6). Od pierwszej dekady XXI w. największymi stronnikami współpracy z Chinami w rosyjskich elitach władzy są: Igor Sieczin, jeden z najbliższych zauszników Putina, odpowiedzialny za rosyjski sektor energetyczny i osobiście zaangażowany w rozwój relacji z Chinami. Igor Iwanow (do sierpnia 2016 r.) oraz Dmitrij Rogozin, związani z kompleksem wojskowo-przemysłowym; generalnie rzecz biorąc sektor energetyczny pozostaje zwolennikiem współpracy z Chinami, uznając to raczej za szansę niż za zagrożenie (i to pomimo trudności w negocjacjach z Chińczykami); podobnie stanowisko ma biurokracja państwowa, której model społeczno-polityczny Chin odpowiada (Kaczmarski, 2015, s. 43). Kolejnymi przykładami zaangażowania najbliższych współpracowników Putina w relacje z Chinami - i korzystania na tych relacjach osobiście - są Giennadij Timczenko (Bond, 2015) i Jurij Trutniew (ten ostatni nie należy do ścisłego grona najbliższych zauszników Putina, ale jest wysłannikiem Prezydenta RF na Rosyjski Daleki Wschód i postacią wpływową w rosyjsko-chińskich komisjach (Китайцы понимают..., 2015). Po części ich zaangażowanie wynika z korzyści osobistych: Chiny zrobiły „zwrot ku przyjaciołom Putina”, obdarzając takich ludzi jak Timczenko dobrymi kredytami oraz podpisując korzystne umowy energetyczne po to, by ekipa Putina patrzyła na Chiny korzystnym okiem (Gabuev, 2015). Tyle jeśli chodzi o zwolenników współpracy z Chinami (którzy przeważają); wśród bardziej zdystansowanych aktorów instytucjonalnych znajdują się: armia oraz służby specjalne, borykające się ze szpiegostwem ze strony Chin i wciąż w jakiejś części operujące paradygmatem (przyszłego) zagrożenia Chin dla Rosji. Nie zmienia to faktu, że zwolennicy współpracy i zacieśniania kontaktów przeważają, zaś wśród elit kremlowskich panuje konsensus na temat tego, że Chiny nie stanowią zagrożenia dla reżimu rosyjskiego (Kaczmarski, 2015, s. 43).

Rosyjskie elity są świadome rosnącej asymetrii na rzecz Chin i negatywnych konsekwencji z tego płynących (takich jak staczanie się do roli „Zaplecza surowcowego” Pekinu), mają również świadomość, że Rosja potrzebuje Chin bardziej niż vice versa (Lo, 2015, Trenin 2013; Лукин, 2007). 
Tym niemniej, od kryzysu światowego w 2008 r. wybierają mimo wszystko współpracę i powodem nie jest (tylko) korupcja osobista - tych powodów jest co najmniej dziesięć. Po pierwsze, rosyjskie elity uznają, że rosnące Chiny stanowią raczej szansę niż zagrożenie, gdyż Chiny są dla Rosji wschodzącym mocarstwem, które nie stanowi zagrożenia (Kaczmarski, 2015, s. 47-48). Po drugie, pomimo prób w równoważeniu Chin (do 2008 r.) Rosja nie zdołała uczynić tego w skuteczny sposób, zdecydowała więc że bardziej opłaca się współpracować. Po trzecie, wzrost Chin nie zagraża Rosji, przynajmniej na razie, ponieważ Moskwa zdaje sobie sprawę, że obecnie strategiczne ambicje Chin są skoncentrowane gdzie indziej. Po czwarte, Chiny zasadniczo respektują rosyjską strefę wpływu w „bliskiej zagranicy" (w sferze politycznej i wojskowej), ze zrozumieniem podchodzą do rosyjskich działań na tym obszarze, a ta chińska empatia łagodzi lęki i zmniejsza rywalizację gospodarczą. Po piąte, chociaż Rosjanie są pod wrażeniem sukcesu chińskiej transformacji, na który patrzą z mieszanką podziwu i zazdrości, pozostają sceptyczni co do długofalowego sukcesu reform: zdają sobie sprawę, że chińska modernizacja wciąż trwa, a Chiny czeka jeszcze wiele wysiłku by stać się supermocarstwem (Rozman, 2014, s. 248). Po szóste, rosyjskie elity przyłączają się do Chin nie z powodu chęci skopiowania "chińskiego modelu” (wymagałoby to zbyt wielu reform wewnętrznych mogących podkopać reżim Putina), lecz z powodu chęci dywersyfikacji powiązań ekonomicznych - tak, by nie być zależnym tylko od Zachodu i tym samym minimalizować zależność od globalnej, zdominowanej przez Zachód gospodarki światowej. Innymi słowy jest to zabezpieczanie się przed ryzykiem ekonomicznym i geopolitycznym (Lo, 2015, s. 27). Po siódme, Chiny nie ingerują w wewnętrzne sprawy Rosji (Лукин 2013, s. 629). Wreszcie, po ósme, wzrost Chin automatycznie oznacza osłabienie globalnej hegemonii amerykańskiej - tworzy bardziej zrównoważony system międzynarodowy, dający Moskwie więcej miejsca na manewr. Po dziewiąte, Rosja, chociaż obawia się Chin długofalowo, zdaje sobie sprawę, że chińskie resentymenty są skierowane w pierwszej kolejności przeciwko Zachodowi, a dopiero potem przeciwko Rosji. Wreszcie po dziesiąte, kryzys ukraiński dał kolejny powód: emocjonalny - wsparcie Chin dla rosyjskiego stanowiska, aczkolwiek połowiczne, zostało zinterpretowane w Rosji jako poparcie w trudnej chwili i stanowiło „rodzaj grupowej psychoterapii dla rosyjskiego przywództwa po traumie kryzysu ukraińskiego. 
Niełatwe poczucie izolacji i wściekłość na - ich zdaniem - zdradę Zachodu, połączyło się z poczuciem odradzania się mocarstwa po aneksji Kry$\mathrm{mu}$, a to z kolei wymusiło potrzebę znalezienia bratnich dusz na arenie międzynarodowej" (Gabuev, 2015).

\section{Percepcja Putina i Rosji w Chinach}

W Chinach doceniono zasługi Putina, który pozostaje popularny w Państwie Środka za swój wizerunek walczącego z korupcją, oligarchami oraz Amerykanami: jest swoistą marką i aż do czasu pojawienia się Xi Jinpinga był popularniejszy w społeczeństwie chińskim od miejscowych przywódców (Китайцы понимают..., 2015). Po części wynika to z dobrej prasy nad Jangcy: według chińskich publicystów Putin „przywrócił stabilność i przewidywalność do rosyjskiej polityki” (Kaczmarski, 2015, s. 48). Jego centralistyczne i autorytarne tendencje przyjęto w Pekinie ze zrozumieniem, a nawet jak oczywistość - powrót do normalności. Bowiem dla elit chińskich, rosyjska transformacja przez lata była negatywnym dowodem na to, że demokracja i wolność słowa nie opłacają się, zaś modernizując kraj, szczególnie tak wielki, potrzeba autorytaryzmu, nie demokracji, która w Rosji zakończyła się klęską (Pyffel, 2009). Putin, w swoim stylu rządzenia odwołujący się do przekonania, iż wolność grozi anarchią (Путин, 2012) przemawia do Chińczyków, dla których Rosjanie inicjując pierestrojkę otworzyli tak zwaną „puszkę Pandory” konfliktów narodowościowych i społecznych, a potem „stracili kolejną dekadę próbując zagnać wszystkie duchy z powrotem do niej (puszki)", rosyjski model transformacji nie mógł być atrakcyjny (Rozman, 2014, s. 190-224). Dekada Jelcyna ma fatalną opinię w Chinach: według Yu Bina Rosja stała się „zdemoralizowana i zdestabilizowana $w$ polityce, $\mathrm{z}$ »terapią szokową « $\mathrm{i}$ chaosem $\mathrm{w}$ gospodarce i zepchnięta i zmarginalizowana strategicznie" (Yu Bin, 2001). Według tej narracji Rosja stała się ofiarą Zachodu, chcącego utrzymywać Rosję słabą, podzieloną i niezdolną do obudowy swojej tożsamości. Narracja ta w pośredni sposób sugeruje, że Zachód stosuje podobną strategię wobec Chin (Rozman, 2014, s. 143). W takich warunkach nie dziwi, że powrót Putina jako silnego człowieka przyjęto w Pekinie ze zrozumieniem - Putin wpisuje się bowiem dobrze w chiński archetyp sprawowania władzy (Pyffel, 
2009). Dla Chińczyków Władmir Putin był pragmatyczną odpowiedzią Rosji na chaos i frustrację wynikającą z reguł świata postzimnowojennego (Yu Bin, 2001). Z punktu widzenia Pekinu, Putin odbudował Rosję: przeszła ona od chaosu do stabilności, od podziału do ponownej centralizacji i od biedy do początkowego dobrobytu, co kontrastowało $\mathrm{z}$ „terapią szokową" Jelcyna, czyli brakiem rozwoju, za to z dużą ilością (negatywnych) igrzysk. W tym chińskim ujęciu putinizm oznacza „stabilność polityczną, etatyzm ekonomiczny oraz aktywniejszą i bardziej nacjonalistyczną politykę zagraniczną" i jest czymś całkowicie naturalnym na tle upadku czasów jelcynowskich (ibidem; Yu Bin, 2008) Chińczycy zdają sobie jednocześnie sprawę z ambicji mocarstwowych Putina i są świadomi, że relacje z Chinami są tylko krokiem na drodze do obudowy statusu mocarstwa przez Rosję (Yu Bin, 2013).

Pochwały wobec obecnego Prezydenta Rosji są zresztą częścią chińskiej strategii schlebiania Rosji, co Chińczycy stosują skutecznie od dawna. Nie krytykują Rosji, za to wychwalają jej odrodzenie i wielkomocarstwowy status, publicznie okazując im szacunek i grając na rosyjskiej megalomanii, zarówno narodowej, jak i osobistej Putina, zdając sobie doskonale sprawę, że tak właśnie należy postępować z Rosją (Trenin, 2000, s. 47; Lo, 2015, s. 144). W rzeczywistości są jednak bardzo krytyczni wobec Federacji Rosyjskiej, uznając ją za państwo ekonomicznie słabe, nieatrakcyjne inwestycyjnie, które przegrało zimną wojnę i nie może się równać z państwami Zachodu, nie mając Chinom wiele - poza surowcami i bronią - do zaoferowania. Mimo uznania, że Rosja za Putina cofnęła się znad przepaści, Chińczycy widzą strukturalne słabości Rosji, szczególnie w sferze ekonomicznej - fakt, że Rosja nie zdołała się zmodernizować i zintegrować z gospodarką światową (Kaczmarski, 2015, s. 48). Ponadto Chińczycy, mając złe doświadczenia historyczne, nie mają wiele zaufania do Rosji, jednak z pragmatycznych względów utrzymują dobre relacje i iluzję wielkiej przyjaźni rosyjsko-chińskiej.

\section{Chiny Xi Jinpinga}

W 2012 r. doszło do zasadniczej zmiany w chińskiej polityce, jaką było dojście do władzy V pokolenia przywódców ChRL, na czele z Xi Jinpin- 
giem. W przeciwieństwie do poprzedników (Hu Jintao, Jiang Zemina), Xi jest silnym przywódcą, który szybko skonsolidował władzę osobistą, a następnie umocnił ją, narzucając tzw. „kampanię antykorupcyjną” (Bloomberg, 2016), kwestionując konsensus wprowadzony przez Deng Xiaopinga, i to zarówno w polityce wewnętrznej (kolektywne przywództwo), jak i zagranicznej („nie wystawiać głów”), otwarcie nawiązując do jednoosobowych wzorców sprawowania władzy nieznanych od czasów Mao Zedonga (Godement, 2013), próbując nawet inicjować własny kult jednostki (Góralczyk, 2016). Personifikował tym wzrastającą rolę Chin na świecie i idącą za tym asertywność (The Economist, 2013). W polityce wewnętrznej rządy Xi oznaczają próbę odbudowy dominacji partii w życiu gospodarczym kraju: to postawa nakazowo-rozdzielcza, z akcentem na kontrolę i nadzór (Godement, 2013). W tej wizji brak miejsca na polityczną liberalizację, a Xi ponoć cytował ZSRR jako negatywny przykład wprowadzania wolnościowych reform (The Economist, 2013). Modernizacja w stylu Xi to modernizacja twardogłowa, łącząca XIX-wieczny realizm polityczny z partyjnymi wzorcami z nadzieją na wzmocnienie pozycji Chin na arenie międzynarodowej (Godement, 2013). Jednak wizja Xi Jinpinga jest dalece nie jedyna: skłania się on ku jednej z trzech głównych szkół myślenia „o chińskim modelu rozwoju”, konkretnie ku szkole „marzycieli” (od „chińskiego marzenia/snu”), wierzących że świat wkroczył już w okres postamerykański (w tym ujęciu USA jest słabnącą potęgą, która prędzej czy później ustąpi Chinom). Jednak „marzyciele” nie są jedyni: obok nich występują konserwatyści na czele z Hu Angangiem, akcentujący chińskie dziedzictwo, zwracający się ku chińskiej kulturze i cywilizacji; oraz pragmatyści na czele z Chi Fulianem, głoszącym iż pierwszy etap transformacji się skończył i Chiny potrzebują „drugiej reformy”: więcej sprawiedliwości społecznej (Góralczyk, 2016, ss. 40-61). Na Xi Jinpinga najwięcej wpływają jednak „marzyciele”, których nazwa pochodzi od książki Chińskie marzenia (zhongguo meng) Liu Mingfu, której główna teza głosi, że Chiny powinny odzyskać swoją pozycję najpotężniejszego państwa na świecie; pozycję, jaką posiadały przez stulecia do XIX w. By tak się stało, Chiny potrzebują „chińskiego marzenia” by stworzyć chińską erę: świat bez hegemonów, z Chinami na czele. By zrealizować tę wizję Chiny potrzebują zreformować gospodarkę, wzmocnić państwo, armię, politykę zagraniczną oraz skupić się na relacjach ze słabnącym hegemonem - Stanami Zjednoczonymi (Liu 
Mingfu 2015, ss. 69-73, 103-124). Koncepcja „chińskiego marzenia” stała się popularna, gdy Xi Jinping zaczął używać tego terminu (Xi highlights..., 2012). W jego retoryce zostało ono połączone $\mathrm{z}$ „wielkim odrodzeniem narodu chińskiego" i stworzyło parę symbolizującą nową asertywność chińskiej polityki (Góralczyk, 2013). „Chińskie marzenie” naturalnie nawiązuje do „amerykańskiego marzenia”, ale jego znaczenie jest inne. Nie chodzi w nim o dobrobyt klasy średniej, lecz o odrodzenie Chin jako wielkiego mocarstwa. Jest to koncepcja odmienna nie tylko $\mathrm{z}$ tego punktu widzenia: również z chińskiego różni się od wszystkich innych sloganów komunistycznych po 1976 r. - odwołuje się do emocji, nie nawiązuje do partyjnej polityki, jest przejęciem koncepcji zagranicznej i ma raczej inspirować niż informować (Xi Jinping..., 2013). Celem jest wzmocnienie legitymizacji wewnętrznej KPCh.

Wiele elementów „chińskiego marzenia” znajduje się w koncepcji polityki zagranicznej Xi, w której wezwał on do nowego modelu rozwojowego i dwóch celów na nowe stulecie: zbudowania społeczeństwa umiarkowanego dobrobytu do 2021 r. oraz, co ważniejsze, realizacji „chińskiego marzenia” o odrodzeniu narodu chińskiego (Xi Jinping, 2014, s. 38). Hasła Xi dobrze świadczą o odradzaniu się tradycyjnego sinocentryzmu w chińskiej polityce zagranicznej, sama bowiem koncepcja jest niemal wprost sinocentryczna (Rozman, 2014, s. 171, 246), stanowiąc być może pierwszy krok na drodze do odbudowy tradycyjnego porządku sinocentrycznego w Azji (Miller, 2017). Bez względu na to czy tak jest w rzeczywistości, Xi Jinping skutecznie zakwestionował dotychczasową politykę Deng Xiaopinga nakazującą skromność w polityce zagranicznej.

\section{Putinizm a „chińskie marzenie”. Podobieństwa i różnice}

Współczesne ideologie państwowe Rosji i Chin łączy wiele aspektów, z których trzeba wymienić najważniejsze: rewizjonizm w stosunkach międzynarodowych (przeciwstawianie się amerykańskiej hegemonii); retoryka "godnościowa” (głoszenie „powrotu na należne miejsce w świecie”) skierowana głównie do własnej opinii publicznej; fundamentalne odrzucenie demokracji jako systemu politycznego prowadzącego do anarchii oraz wiążące się z tym ograniczenie praw i swobód obywatelskich. Nieco podobne 
są również rewanżystowskie motywacje w polityce wobec Zachodu (poczucie wychodzenia z narzuconej przez Zachód słabości i chęć „oddania” za krzywdy z przeszłości.)

Jednak rozbieżności są równie ważne. Putinizm i „chińskie marzenie” różnią podglebie kulturowe, na którym zostały uformowane (pęd do mocarstwowości, idea „ruskiego świata” oraz militaryzm po stronie rosyjskiej; sinocentryczna wizja świata po stronie chińskiej), co ma o tyle istotne znaczenie, iż te czynniki kulturowe kształtują długoterminowe cele polityki międzynarodowej Rosji i Chin. Szczególnie w przypadku Rosji powoduje to akcent na kwestie wizerunkowe i symboliczne: udowodnienie całemu światu, w tym samym siebie, że jest się mocarstwem stanowi raison d'être polityki Putuina i jego drużyny. Chiny, chociaż również czułe na punkcie swojego statusu, nie mają aż takiej potrzeby demonstrowania własnej pozycji w stosunkach międzynarodowych wybierając raczej zaniżanie swego znaczenia niż zawyżanie go. Najważniejsze różnice widać w dwóch aspektach: gospodarczym i społecznym. W przypadku Rosji putinizm oznacza kombinację władzy biurokratycznej i urzędniczej powiązanej więzami personalnymi, powodującą strukturalne niewydolności: łączenie władzy i własności, korupcję, pogoń za rentą, etatyzm i despotyzm. Na tle chińskiej wydolności gospodarczej, a także sporej wolności gospodarczej system rosyjski prezentuje się blado. Jest w nim natomiast - w porównaniu do chińskiego - znacznie więcej wolności osobistych. W Chinach nie do pomyślenia są protesty na wielką skalę, relatywnie wolny Internet czy kilka $\mathrm{w}$ miarę niezależnych mediów.

\section{Relacje osobiste Władimira Putina i Xi Jinpinga}

Relacje osobiste Putina i Xi stanowią istotny element tej „osobowościowej” analizy relacji rosyjsko-chińskich. Jest to istotne zarówno z powodu ważności relacji osobistych w kulturach chińskiej i rosyjskiej, a także z przyczyn osobowości samego Władimira Putina, dokładającego wielkich starań do dyplomacji indywidualnej, stanowiącej jego ulubioną formę dyplomacji, preferowaną nad relacjami międzyrządowymi (instytucjonalnymi) czy multilateralnymi (Gabuev, 2016). Ponoć Putin i Xi darzą się sympatią, a przynajmniej tak twierdzi ten pierwszy (Oтветы..., 2016), jak 
również wpływowi komentatorzy («Китайць понимают, что..., 2015). Ma to stanowić odmianę wobec relacji Putina z poprzednimi chińskimi przywódcami: Jiang Zeminem oraz Hu Jintao, pozbawionych głębszych sympatii i opartych na czysto biznesowym modelu (Trenin, 2015). Z kolei Putin i Xi, mimo bariery językowej, zbudowali dobre relacje osobiste (Gabuev, 2016). Podobno polubili się na szczycie APEC w 2013 r., podczas którego Putin świętował urodziny, m.in. z Xi (ibidem). Dobre relacje osobiste z Xi Jinpingiem są dla Putina ważne, gdyż krąg jego osobistych przyjaciół wśród wpływowych przywódców politycznych świata ostatnio zmalał - Xi Jinping pozostaje w zasadzie jedynym z najważniejszych przywódców światowych mających przyjacielskie relacje z Putinem. (ibidem.)

Putina i Xi Jinpinga łączy spojrzenie na politykę wywiedzione z dziewiętnastowiecznego realizmu politycznego. Według rosyjskiej prasy Xi Jinping miał powiedzieć Putinowi, że mają wspólne charaktery (Пymuн u Cu..., 2013). Na pewno zaś wspólne traumatyczne doświadczenia z przeszłości: obaj przeżyli najgorsze chwile swoich krajów - Xi Jinping rewolucję kulturalną w Chinach, Putin rozpad ZSRR - i obaj wywiedli z tych doświadczeń przekonanie, że porządek jest ważniejszy od wolności (Yu Bin, 2013). Stąd bierze się odrzucenie zachodnich wartości demokracji i praw człowieka oraz irytacja przechodząca nieraz we wściekłość na mieszanie się państw zachodnich w obronie tych wartości w ich krajach, chociaż w wytykaniu Zachodowi hipokryzji prym wiedzie Putin, to i Xi Jinping wypowiadał się w tym duchu (Gabuev, 2015). Zarówno Putin, jak i Xi Jinping są - patrząc z punktu widzenia filozofii politycznej - realistami politycznymi (z wszystkimi różnicami kulturowymi rzecz jasna), marzącymi o przywróceniu utraconej chwały ich państwom i końcu amerykańskiej hegemonii. Chociaż w wielu obszarach ich interesy nachodzą na siebie lub są po prostu rozbieżne, ta wspólnota ideowa nie powoduje poważnych konfliktów: nawet jeśli się ze sobą nie zgadzają, to nie palą mostów, oferują sobie bezcenne rzeczy w polityce: przewidywalność i stabilność. Ich dobre relacje osobiste przekładają się na interesy gospodarcze: przykładowo 12-miliardowa pożyczka chińskich banków dla Jamał LNG, sprzedaż udziałów w Sibur Sinopecowi czy umowy mające kredytować kolej szybkich prędkości Moskwa-Kazań bez gwarancji państwowych - to wszystko zasługa relacji osobistych Xi Jinpinga i Putina (Ради дружбы..., 2016; Gabuev, 2016). Wreszcie relacje osobiste Xi Jinpinga i Putina wzmacniają sto- 
sunki rosyjsko-chińskie tworząc „nowy element strukturalny”: dając im „stabilność kadrową” (Trenin, 2015).

\section{Niełatwe zaprzyjaźnianie społeczeństw}

Dobre relacje między przywódcami Rosji i Chin wciąż nie przekładają się na tak dobre relacje między rosyjskimi i chińskimi elitami, o narodach nie wspominając, aczkolwiek obecnie jest lepiej, niż było do tej pory. Rosyjskie i chińskie elity próbują się porozumieć i znaleźć wspólny język - dosłownie (najczęściej jest to angielski, a nie jak jeszcze do lat 90., rosyjski) oraz metaforycznie: zarówno przedstawiciele elit chińskich, jak i rosyjskich podchodzą do siebie z rezerwą. Ten dystans jeszcze bardziej zwiększa się na poziomie społecznym, masowym: dekadę temu mówiono o tym, że „na górze ciepło, na dole zimno”, teraz wszędzie jest cieplej, ale do lata daleka droga.

Społeczeństwa lub masy zawsze były słabym punktem w rozwijających się i odbudowujących się po $1991 \mathrm{r}$. relacjach rosyjsko-chińskich. Jeśli na poziomie elit Rosjan i Chińczyków połączyła geopolityka i interesy (najpierw broń, potem także surowce), tak na poziomie społecznym tych punktów wspólnych zawsze było mało (Rozman, 2014, s. 268). Pomimo bezprecedensowego postępu w relacjach wzajemnych, problemem pozostała trudna do uchwycenia kwestia wzajemnej percepcji społeczeństw rosyjskiego i chińskiego. Jeszcze dekadę temu Rosjanie i Chińczycy „mało o sobie wiedzieli i jeszcze mniej się lubili; o sympatii nie mogło być mowy (Yu Bin, 2006). Zwracali na to również uwagę badacze rosyjscy podkreślający przepaść pomiędzy coraz lepiej rozumiejącymi się elitami a społeczeństwami Rosji i Chin (Титаренко, 2008, s. 264). Uznawano to za wyzwanie dla dalszego rozwoju relacji bilateralnych (Yu Bin, 2006). Badania opinii publicznej pokazywały wzajemny dystans, jeśli nie niechęć między zwykłymi Rosjanami a Chińczykami (Kuchins, 2010, s. 47). Do tego dochodziły wzajemne stereotypy: zarówno te stare, wielowiekowe - Rosjan jako „owłosionych barbarzyńców z Północy” (w Chinach) oraz Chińczyków jako dzikie hordy ze Wschodu (w Rosji) - jak i nowe opierające się na założenie, że Rosjanie nie chcą zaakceptować wzrostu Chin, prezentują carski imperializm, mają w swoim kraju chaos i nieporządek, a z drugiej strony Chińczycy mają być obcy kulturowo, aroganccy i dążyć do nowych nierównopraw- 
nych - tym razem dla Chin - traktatów (Rozman, 2014, s. 251-269). Rosja dla chińskiej młodzieży nie jest zbyt interesująca ani atrakcyjna. Chińczycy rozumieją, że Rosja była mocarstwem i nadal chciałaby być, ale z powodu korupcji i złego zarządzania upadła - pozostały jej wielkie terytoria oraz broń jądrowa («Китайцы понимают, что..., 2015). Brak silnych związków z Azją, pozostałości myślenia w kategoriach europejskiej wyższości (ze strony Rosji) oraz silnie zakorzeniony sinocentryzm (w Chinach) dodatkowo utrudniają sprawę. Rzecz jasna te cechy są trudno dostrzegalne, gdyż wzajemny brak sympatii jest równoważony przez niechęć do krytyki, szczególnie silną w chińskiej kulturze (Rozman, 2014, s. 259), jednak istnieją one i czasem dają o sobie znać.

Zdają sobie z tego sprawę władze zarówno Rosji, jak i Chin, próbujące odpowiednio ukształtować swoje społeczeństwa pod linię władzy. Dekadę temu organizowali Rok Chin w Rosji oraz Rok Rosji w Chinach (a potem odpowiednio Rok Języka Rosyjskiego w Chinach i Rok Języka Chińskiego w Rosji) i tego typu podobnie organizowane odgórnie wydarzenia (Лукин, 2013, s. 350). Ponadto przekaz płynący ze strony obu rządów - rosyjskiego i chińskiego - do swoich społeczeństw jest jasny: władza chce by społeczeństwa się polubiły. To dlatego w rosyjskich mediach od co najmniej dekady przeważa pozytywny obraz Chin. Działania te zintensyfikowały się po kryzysie ukraińskim, podczas którego Chiny zachowały życzliwą neutralność (zinterpretowaną w Rosji jako przychylność) wobec działań Rosji. Po tym wydarzeniu Rosja wyzbyła się (lub chociaż zawiesiła na jakiś czas) podejrzenia wobec Chin - od tego momentu w Rosji panuje swoista moda na Chiny: od 2014 r. w rosyjskiej telewizji znacząco wzrosły (pozytywne) programy o Chinach, w rosyjskich księgarniach popularne są książki o Chinach, zaś między oboma państwami intensywnie rozwija się współpraca akademicka, w ostatnich latach jeszcze bardziej zintensyfikowana to wszystko tworzy pozytywny obraz Chin w Rosji (ibidem, s. 401-405). W połączeniu z rosyjskim poczuciem zdradzenia przez Zachód tworzy to dobre podstawy do zbliżenia również na poziomie społecznym. Natomiast jeśli chodzi o Chiny, to w kontrolowanych przez Pekin mediach obraz Rosji jest pozytywny lub neutralny; telewizja i prasa chińska zazwyczaj przedstawiają spory Rosji z Zachodem w sposób korzystny dla Rosji oraz rzecz jasna tworzą wspaniały obraz relacji rosyjsko-chińskich. Rezultatem tego jest postrzeganie, że Rosji w Chinach poprawia się, także wśród młod- 
szego pokolenia, gdyż - używając nomenklatury chińskiej - „Rosja opiera się międzynarodowemu hegemonizmowi" (Duchâtel, 2016), a zdaniem wielu jest nawet państwem przyjaznym Chinom (Лукин , 2013, s. 662). Тę prorosyjską sympatię w części tworzy (wśród starszego pokolenia) postkomunistyczna nostalgia wśród osób pamiętających „wspólną walkę o socjalizm" (Yu Bin, 2017, s. 103-116). Z drugiej strony nie jest to ograniczone tylko do emerytów. Przykładem działań rosyjskich zasadniczo popierających atmosferę społecznych relacji rosyjsko-chińskich jest fakt zauważalnej poprawy zachowania rosyjskich policjantów wobec chińskich turystów (Duchâtel, 2016) - jeszcze kilka lat temu policjanci byli zmorą Chińczyków (zresztą nie tylko ich), a popularne powiedzenia głosiło, że w Rosji nie znalazłby się żaden Chińczyk nieposzkodowany przez policję. To powiedziawszy, pozytywny wzajemny obraz ma swoje ograniczenia. Przede wszystkim jest tylko częściowy (dla zdecydowanej większości społeczeństwa chińskiego Rosja jest obojętna), a ponadto Chińczycy mają lepsze zdanie o Rosjanach niż Rosjanie o Chińczykach (mimo rosnącej popularności Chin w społeczeństwie rosyjskim nadal nierzadkie są tam postawy antychińskie, Goldstein, 2017). To zaś powoduje, że wszystkie próby skłonienia obu narodów do polubienia się, do poprawy relacji międzyludzkich, są tylko częściowo skuteczne. Wzajemne lęki i resentymenty - jak te na Rosyjskim Dalekim Wschodzie - nie zniknęły, po prostu zeszły do „podziemia” publicystycznego. Rozmowy prywatne z Rosjanami i Chińczykami dają namiastkę tego, co pokazują badania socjologiczne: że pomimo intensyfikacji kontaktów między zwykłymi Rosjanami i Chińczykami wzajemna sympatia znacząco nie wzrasta (szczególnie po rosyjskiej stronie, Прошание с..., 2014). Kolejnym barometrem nastrojów w społecznym odbiorze Rosji w Chinach i Chin w Rosji jest Internet, medium najmniej ocenzurowane w obu tych państwach. Chociaż kwestie rosyjsko-chińskie nie są głównymi newsami ani też nie rozpoczynają wielkich dyskusji, czasem tak się zdarzy, szczególnie w sytuacjach kontrowersyjnych, takich jak zanieczyszczenie dalekowschodnich rzek przez Chińczyków, zatopienie chińskiego statku czy zamknięcie chińskiego bazaru w Moskwie. W momencie, gdy dochodzi do takich sytuacji, Internet „wybucha” antyrosyjskimi (w Chinach) i antychińskimi (w Rosji) nastrojami, udowadniając podstawową regułę słabych relacji kulturalnych i wzajemnego braku zaufania na poziomie społecznym (Rozman, 2014, s. 270). Pomimo dobrego stanu 
relacji rosyjsko-chińskich społeczeństwa obu państw wciąż - jak narzeka jeden rosyjski analityk - „mają znaczącą ilość stereotypów i przeterminowanych obrazów”, między oboma narodami „wciąż nie ma wystarczająco dużo zrozumienia” (Лукин , 2013, s. 687). Tym samym, pomimo oficjalnej promocji pozytywnego obrazu Rosji w Chinach oraz Chin w Rosji przez Moskwę i Pekin, relacje rosyjsko-chińskie wciąż borykają się z problemem dobrych relacji na poziomie politycznym i znacznie gorszych na poziomie społecznym (Тихвинский 2008, s. 219). To jednak zbytnio nie martwi elit rosyjskich i chińskich, wychodzących z założenia, że apatia jest lepsza niż antypatia (Rozman, 2014, s. 57 i 267). Poza tym elity rosyjskie i chińskie akurat rozumieją się bez słów w założeniu, że (zwykli) ludzie nie powinni mieć większego wpływu na politykę. I zarówno w Rosji, jak i w Chinach nie mają.

\section{Podsumowanie}

Putin i Xi zdominowali systemy polityczne w swoich państwach, więc od nich samych wiele zależy, w tym przyszłość relacji rosyjsko-chińskich (osobista sympatia między przywódcami jest więc jednym z elementów sugerujących stałość tychże relacji, przynajmniej w okresie krótkoterminowym). Szczęśliwie dla relacji rosyjsko-chińskich Putin i Xi mają darzyć się sympatią, na co bez wątpienia mają wpływ podobieństwa między tymi przywódcami: mimo zasadniczych (i naturalnych, zważywszy na kulturowe odmienności obu krajów) różnic, zarówno Putin, jak i Xi Jinping prezentują spojrzenie realistyczne na stosunki międzynarodowe, inspirowane XIX-wiecznym koncertem mocarstw. Podobny światopogląd i wzajemna sympatia powodują „stabilność kadrową” w relacjach rosyjsko-chińskich - Rosja i Chiny szanują swoje strefy interesów (bliska zagranica dla Rosji, Tajwan i Morze Południowochińskie dla Chin). Dobre relacje przywódców są dla relacji rosyjsko-chińskich znacznie ważniejsze niż chłodniejsze, acz w ostatnim czasie poprawiające się, relacje międzyludzkie społeczeństw rosyjskiego i chińskiego. Potwierdza to starą prawdę, iż takich państwach jak Rosja czy Chiny ludzie (społeczeństwa) nie mają większego znaczenia wobec elit politycznych. 


\section{DR MICHAŁ LUBINA}

Instytut Bliskiego i Dalekiego Wschodu

Uniwersytet Jagielloński

ul. Gronostajowa 3, 30-001 Kraków

michal.lubina@uj.edu.pl

\section{Bibliografia}

Bieleń, S. (2006). Tożsamość międzynarodowa Federacji Rosyjskiej. Warszawa: Oficyna Wydawnicza ASPRA-JR.

Bond, I. (2016). Russia and China Russia and China Partners of choice and Partners of choice and necessity? Centre for European Reform Report.

Chasing the Chinese dream. (2013, 3 maja). The Economist.

Dmochowski, T. (2008). Radziecko-chińskie stosunki polityczne po śmierci Mao Zedonga. Gdańsk.

Duchâtel, M. (2016, 2 listopada). China and Russia: Towards an alliance treaty? W: F. Godement, M. Duchâtel (red.). China and Russia. Gaming the West. ECFR.Eu.

Gabuev, A. (2016, 3 czerwca). Putin-Xi Friendship Driving Russia-China Ties. Moscow: Carnegie Moscow.

Gabuev, A. (2016, 25 czerwca). China’s Pivot to Putin's Friends, Foreign Policy.

Gabuev, A. (2016, 29 czerwca). Friends with Benefits? Russian-Chinese Relations After the Ukrainian Crisis. Moscow: Carnegie Moscow.

Godement, F. (2013, 17 listopada). Xi Jinping's China. London: European Council on Foreign Affairs.

Goldstein, L. J. (2017, 25 kwietnia). A China-Russia Alliance? The National Interest.

Góralczyk, B. (2013). Chiński sen. Komentarz Międzynarodowy Pułaskiego, 3.

Góralczyk, B. (2016). China under Uncle Xi. Aspen Review Central Europe, 2.

Góralczyk, B. (2016). W poszukiwaniu chińskiego modelu rozwojowego, Sprawy Międzynarodowe, 1, 40-61.

Hill, F., Gaddy, C. (2015). Mr. Putin: Operative in the Kremlin. Washington: Brookings.

Kaczmarski, M. (2015). Russia-China Relations in the Post-Crisis International Order. London, New York: Routledge.

Keohane, R. O. (1986). Theory of World Politics: Structural Realism and Beyond.

Kuchins, A. (2010). Russian Perspective on China: Strategic Ambivalence. W: J. Ballacqua (red.), The Future of China-Russia Relations. Kentucky.

Liu Mingfu. (2015). The China Dream: Great Power Thinking and Strategic Posture in the Post.

Lo B. (2008). Axis of Convenience. Moscow, Beijing and the New Geopolitics. London: Chatham House. 
Lo B. (2015). Russia and The New World Disorder. London: Chatham House.

Lubina, M. (2014). Niedźwiedź w cieniu smoka. Rosja-Chiny 1991-2014. Kraków: Księgarnia Akademicka.

Lubina, M. (2017). Russia and China. A Political Marriage of Convenience. Opladen, Berlin, Toronto: Budrich Publishers.

Lukin, A. (2009). Russia's New Authoritarianism and the post-Soviet Polirtical Ideal. Post Soviet Affairs, 25(1), 56-92.

Miller, T. (2017). China's Asia Dream. Empire Building along the New Silk Road. London: Zed Books.

Mommsen, M. (2012). Russia's Political Regime: Neo-Soviet Authoritarianism and Patronal Neorealism and Its Critics. New York: Columbia University Press.

Pipes, R. (2004). Flight from Freedom: What Russians Think and Want. Foreign Affairs, 83(3).

Presidentialism. W: Presidents, Oligarchs and Bureaucrats. Forms of Rule in the PostSoviet.

Pyffel, R. (2009, 16 października). Chiny-Rosja: Kto kogo? polska-azja.pl.

Rozman, G. (2014). The Sino-Russian Challenge to the World Order. National Identities, Bilateral Relations, and East Versus West in the 2010s. Washington, Stanford: Woodrow Wilson Center, Stanford University Press.

Rumer, E.B., Wallander, C.A. (2003/2004). Russia: Power in Weakness. Washington Quarterly, 27(1).

Stewart, S. et all (red.). (2012). Space. Farnham: Ashgate.

Trienin, D. (2000). Challenge and Chance for Russia. W: S. W. Garnett (red.), Rapprochement or Rivalry? Russia - China Relations in a Changing Asia. Washington D.C.

Trienin, D. (2015, 9 kwietnia). From Greater Europe to Greater Asia? The Sino-Russian Entente. Carnegie Center, 8(1).

Xi Calls for a China in 2016 Where 'Nobody Dares to Be Corrupt'. (2016, 13 stycznia). Bloomberg.

Xi highlights national goal of rejuvenation. (2012, 30 listopada). English People.Com.

Xi Jinping. (2014). The governance of China. Beijing.

Yu Bin. (2001). Crouching Missiles, Hidden Alliances. Comparative Connections, $10(1)$.

Yu Bin. (2005). Pollution, Politics and Partnership. Comparative Connections, 7(4).

Yu Bin. (2006). China's Year of Russia and the Gathering Nuclear Storm. Comparative Connections.

Yu Bin. (2008). From Election Politics to Economics Posturing. Comparative Connections, 10(1).

Yu Bin. (2012). Succession, Syria and the Search for Putin's Soul. Comparative Connections, 14(1).

Yu Bin. (2017). China-Russia Relations. Trilateral Politics. Trump Style. Comparative Connections. 
Yu Bin. (2013). Pivot to Eurasia and Africa: Xi Style. Comparative Connections, 15(1). Лукин, А. (2007). Китай: опасный сосед или выгодный партнер. Pro et Contra.

Путин, В. (2012, 16 stycznia). Россия сосредотачивается - вызовы, на которые мы должны Ответить. Известия.

Востоке России. (2014). SLON. Ru.

День рождения Путин отметил тортом и водкой. (2013, 9 października). Эхо Cuбири.

Лукин, А. В. (2013). От нормализации к стратегическому партнерству Россия и Китай после распада СССР. W: А.В. Лукина (red.), Четыре века взаимодействия. История, современное состояние и перспективы развития российско-китайских отношений. Москва.

Лукин, А. В. (2013). Россия и Китай сегодня и завтра. W: Россия и Kuтай: четьре века взаимодействия. История, современное состояние и перспективы развития российско китайских отношений. Ноябрь- декабрь 2007.

Ответы на вопросы журналистов. (2016, 5 września). Kremlin.Ru.

Перспективы. (2000, 9 listopada). Kremlin.Ru.

Прошание с «азиатскими Балканами» Восприятие китайской миграиии на Дальнем Путин и Си Цзиньпин сошлись характерами. (2013, 24 marca). Столетие.

Ради дружбь Путина и Си Цзиньпина. (2016, 17 marca). Inosmi.Ru.

Тихвинский, С. (2008). Воспиятие в Китае образа России. Москва.

Статья Президента России Владимира Путина «Россия: новые восточные

Титаренко, М. (2008). Геополитическое значение Дальнего Востока. Россия, Китай и другие страны Азии. Москва

«Китайць понимают, что Россия деградирует из-за коррупиии и неэфбективного управления» (2015, 30 kwietnia). Lenta.Ru. 